\title{
Implementasi Metode Extreme Programming dalam Pengembangan Sistem Informasi Izin Produk Makanan
}

\author{
Fatoni $^{[1]}$, Dedi Irawan ${ }^{[2]}$ \\ Program Studi Teknik Informatika ${ }^{[1]}$, Program Studi Sistem Informasi ${ }^{[2]}$ \\ Fakultas Ilmu Komputer, Universitas Bina Darma \\ Palembang, Indoneisa, 30264 \\ fatoni@binadarma,.ac.id ${ }^{[1]}$,dedi.irawan@binadarma.ac.id ${ }^{[2]}$
}

\begin{abstract}
Abstrak - Banyaknya produk makanan yang beredar baik yang diproduksi oleh perusahaan skala nasional maupun lokal serta produk makanan yang diproduksi secara illegal menimbulkan permasalahan tersendiri. Salah satu permasalahan yang muncul yaitu kemampuan masyarakat dalam memilih produk makanan yang baik atau berizin untuk diedarkan sebagai pemenuhan kebutuhan. Sehingga informasi tentang produk makanan menjadi sangat penting untuk diketahui. Dengan adanya informasi produk makanan masyarakat dapat melakukan tindakan prepentif bagi dirinya dan lingkungannya Untuk itu didalam peneltian ini dilakukan pengembangan sistem informasi izin produk makanan yang dapat digunakan masyarakat dalam mencari informasi sebuah produk makanan. Didalam proses pengembangan sistem informasi digunakan extreme programming sebagai metode pengembangan dengan tahapan eksplorasi, perencanaan, iterasi pengembangan, produksi, dan pemeliharaan. Dari hasil penelitian menujukkan bawah metode extreme programming mampu menghasilkan sistem infomrasi yang dapat berfungsi secara baik yang ditunjukkan dari hasil pengujian.
\end{abstract}

Kata Kunci-Extreme Programming, Sistem Informasi, Izin

\section{PENDAHULUAN}

Perkembangan tekonologi informasi saat ini telah masuk disegala lini kehidupan umat manusia. Di abad sekarang ini tidak ada satupun hal yang terlepas dari teknologi informasi. Jika dilihat hal sekecil apapun telah dijamah oleh teknologi informasi. Kondisi tersebut dapat dilihat pada dunia pendidikan, pemerintahan, industri, lembaga swadaya masyarakat (LSM), organisasi professi, bahkan di ruang lingkup agama sekalipun. Kondisi tersebut menunjukkan bahawa penggunaan teknologi informasi merupakan kebutuhan primer bagi umat manusia saat ini. kebutuhan primer tersebut dapat dilihat dalam kegiatan sehari-hari setiap orang yang menjadikan teknologi informasi sebagai alat bantu untuk menyelesaikan permasalahan yang dihadapi.

Pada ruang lungkup produksi makanan pemanfaatan teknologi informasi yang dapat dilihat mulai dari persediaan sampai dengan pemasaranan produk. Produk makanan merupakan produk yang memiliki dampak terhadap kehidupan masyarakat. Kondisi tersebut terjadi karena makanan adalah salah satu komponen penting agar seseorang dapat bertahan hidup. Untuk mendapatkan kualitas hidup yang baik maka seseorang perlu mengkonsumsi makanan yang sehat. Banyaknya produk makanan yang beredar baik yang diproduksi oleh perusahaan skala nasional maupun lokal serta produk makanan yang diproduksi secara illegal menimbulkan permasalahan tersendiri. Untuk itu informasi tentang produk makanan menjadi sangat penting untuk diketahui. Dengan adanya informasi produk makanan masyarakat dapat melakukan tindakan prepentif bagi dirinya dan lingkungannya.

Merujuk dari uraian diatas yang dapat disimpulkan bahwa tidak semua makanan yang beredar merupakanan makanan sehat. Untuk itu pengelolaan informasi produk makanan beredar ditengah masyarakat sangatlah penting. Sehingga untuk mengatasi permasalahan tersebut dapat dilakukan dengan cara penyediaan informasi melalui sistem informasi izin produk makanan sehingga dengan adanya sistem informasi ini dapat mebantu masyarakat dan pemerintah untuk mengetahui apakah produk yang dijual telah memiliki izin dan sebaliknya. Dengan demikian masyarakat akan merasa nyaman untuk membeli produk tersebut. Karena sesuai dengan fungsinya sistem informasi melakukan pengolahan data menjadi informasi.

Untuk menghasilkan sistem informasi sesuai kebutuhan maka dalam proses pengembangan digunakan metode pengembangan yang sistematis, terstruktur dan berorientasi pada objek. Terdapat berbagai macam jenis metode pengembangan yang dapat digunakan diantaranya adalah waterfall, rapid application development, spiral, scrum, dan extreme programming. Waterfall merupakan metode pengmembangan terstruktur dengan tahapan analisis kebutuhan, perancangan, pengkodean, dan pengujian \& pemeliharaan [1]. Dalam kajian yang lain waterfall memiliki tahapan communication, planning, modeling, construction dan deployment [2]. Sedangkan rapid application development dan spiral memiliki kesamaan dengan waterfall yaitu sama-sama metode pengembangan terstrukur atau pengembangan tradisional dengan tahapan

ISSN : 2301-7988

E-ISSN : 2581-0588

DOI $\quad: 10.32736 /$ sisfokom.v8i2.679 
pengembangan perencanaan, desain antarmuka, pengkodean dan cutover [3, 4]. Sedangkan spiral dengan tahapan preparation, conception, realization, dan go live \& support [5]. Scrum dan extreme programming merupakan metode pengembangan turunan dari agile. Dimana scrum memiliki tahapan product backlog, sprint backlog, sprint, dan iterasi produk. Sedangkan extreme programming memiliki tahapan eksplorasi, perencanaan, iterasi pengembangan, produksi, dan pemeliharaan [6].

Berdasrkan uraian tersebut maka dalam proses pengembangan sistem informasi produk makanan ini digunakan metode extreme programming. Penggunaan extreme programming disebabkan beberapa hal nilai dasra yang dimilinya yaitu: (1) komunikasi, yaitu mengedepankan komunikasi kepada pelanggan, (2) kesederhanaan, mengedepankan kesederhanaan dalam proses pengembangan, (3) umpan balik, memberikan keleluasaan memberikan umpan balik kepada pelanggan, dan (4) keberanian, memberikan nilai keberanian dalam proses pengembangan. Dari empat nilai dasar ini extreme programming menunjukkan bahwa dalam proses pengembangan menjunjung tinggi nilai fleksibel baik dalam proses perubahan maupun kemungkinan lain dalam proses pengembangan [7]. Selain itu metode waterfall, rapid application development, spiral merupakan metode pengembangan tradisional yang lebih mengedepankan struktur dalam proses pengembangan.

\section{Metodologi Penelitian}

\section{A. Metode Penelitian}

Dalam melakukan implementasi extreme programming dalam pengembangan sistem informasi izin produk makanan ini digunakan metode penelitian deskriptif. Penggunaan metode ini disebabkan yang akan dilakukan merupakan pengungkapan fenomena dan fakta yang dilakukan oleh peneliti [8]. Selain itu juga metode deskriptif berfokus pada peneliti dalam menjabarkan sebuah objek [9].

\section{B. Objek Penelitian}

Implementasi metode extreme programming dalam pengembangan sistem informasi izin produk makanan dapat dilakukan pada pemerintah tinggkat daerah baik pada pemerintah provinsi maupun kabupaten. Dalam penelitian ini dilakukan implementasi pada Kota Lubuklinggau sebagai bahan uji coba implementasi.

\section{Metode Extreme Programming}

Extreme programming merupakan salah satu metode pengembagan turunan dari agile development. Agile development adalah teknik pengembangan yang dapat dilakukan dengan cepat atau dalam artian pemenuhan kebutuhan perangkat lunak atau sistem informasi yang melibatkan pengguna dengan tujuan meminimalisir kesalahan pengembangan [10]. Extreme programming metode pengembangan dengan fokus utama pada tim dengan semboyan "technical how to" yang berpegang pada prinsip-prinsip agile methodology yang tediri dari: "(1) memproritaskan kepuasan pelanggan, (2) terbuka ketika ada perubahan, (3) memberikan hasil pekerjaan secara berkala, (4) pengembang dan client berkerja bersama-sama, (5) memberikan motivasi personal anggota tim, (6) membuat cara efektif dan efisien dalam pengumpulan informasi, (7) memproritaskan kemajuan proyek, (8) menjaga keberlanjutan hubungan antara pihak sponsor, pengembang dan pengguna, (9) memberikan perhatian lebih terhadap hal teknis, (10) membuat sesuatu sesederhana mungkin, (11) menghasilkan arsitektur, kebutuhan, dan perancangan dari tim sendiri, dan (12) berusaha melakukan pekerjaan secara efektif dan dilakukan secara berkala" [11]. Untuk itu sebagai penyelesaian implementasi sitem informasi produk makanan menggnakan extreme programming dengan tahapan seperti yang diperlihatkan pada Gambar 1 yaitu (1) exploration, (2) planning, (3) iteration, (4) production dan (5) maintenance [12].

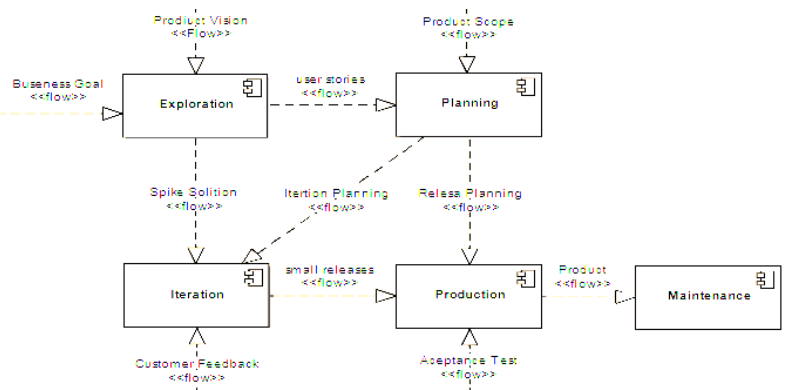

Gambar 1. Proses Pengembangan extreme programming

Proses pengembangan yang diperlihatkan pada Gambar 1 dapat dijelaskan sebagai berikut:

- Eksplorasi, tahapan explorasi merupakan tahapan untuk melakukan pengumpulan kebutuhan. Setelah kebutuhan didapat dilakukan pemmbuatan prototype awal sistem informasi.

- Perencanaan, tahapan perencanaan merupakan tahapan yang melakukan pemilihan kebutuhan yang telah dieksplorasi. Pemilihan kebutuhan dilakukan dengan melibatkan pengguna.

- Iterasi, tahapan iterasi merupakan tahapan yang melakukan iterasi perencananaan yang dibagi menjadi dua jenis yaitu pengerjaan perencangan arsitektur dan pengkodean.

- Produksi, tahapan produksi merupakan tahapan yang pelakukan pengujian produk yang dalam hal ini pengujian sistem informasi yang dihasilkan. Pengujian terus dilakukan sampai produk dianggap sempurna. Pengujian sendiri melibatkan pengguna.

- Pemeliharaan, fase ini fokus pada layanan pendukung setelah perangkat lunak diberikan kepada pengguna (client). Selain itu juga melakukan perbaikan jika diperlukan serta melakukan pengembangan jika diperlukan.

\section{HASIL DAN PEMBAHASAN}

Dari penelitian yang penulis lakukan, didapatkan sistem informasi izin produk makanan dikhusus untuk 
menampilkan informasi tentang izin produk makanan ringan, sistem informasi tersebut terdiri dari beberapa file pendukung yang berakumulasi dalam sebuah project.
Sistem informasi izin produk makanan memiliki struktur menu seperti yang diperlihatkan pada Gambar 2 .

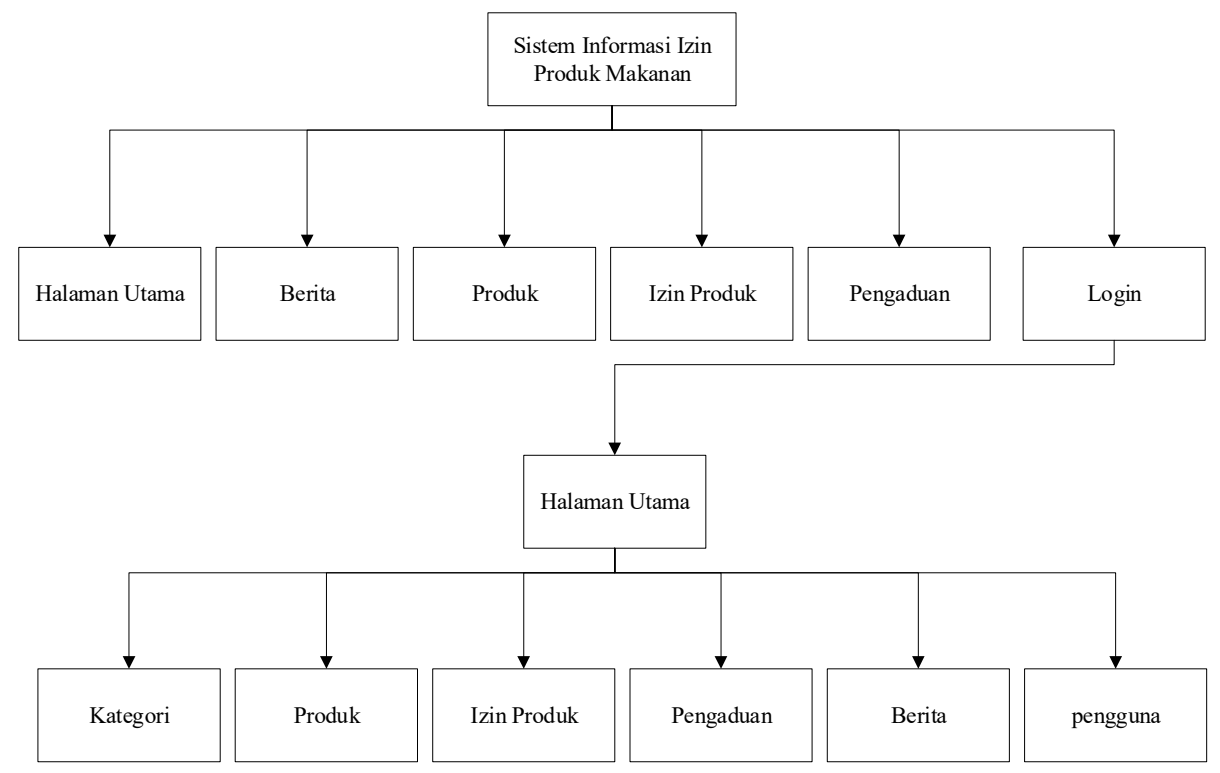

Gambar 2. Struktur menu navigasi sistem informasi

Dari struktur menu yang dibentuk seperti yang diperlihatkan pada Gambar 2 maka masing-masing komponen struktur menu tersebut dapat dijelaskan sebagai berikut:

- Halaman Utama merupakan merupakan tampilan utama dari sistem informasi izin produk makanan yang berisikan gambar grafis produk makanan.

- Halaman berita merupakan halaman yang menyajikan informasi berita seputar kesehatan dan produk makanan yang diperuntukkan sebagai pengetahuan bagi masyarakat.

- Halaman produk berisikan informasi tentang semua daftar produk yang telah didaftarkan pada sistem informasi izin produk makanan yang dapat dilihat oleh semua pemangku kepentingan baik masyarakat maupun pemerintah.

- Halaman izin produk merupakan halaman yang menampilkan informasi izin produk makanan yang adapa pada sistem informasi izin produk makanan. Informasi yang ditampilkan meliputi nama produk, nomor surat, mulai berlaku izin produk dan kadaluarsa izin produk.

- Halaman pengaduan merupakan halaman yang dikhusukan untuk masyarakat untuk melakukan pengaduan kepada pihak terkait terutama kepada pemerintah jika menemukan produk makanan yang tidak berizin atau kondisi lainnya yang perlu untuk dilaporakan.

A. Ekslorasi

Sesuai dengan extreme programming pada tahapan ini dilakukan ekslpolrasi kebutuhan. Seperti yang diperlihatkan pada Gambar 2 merupakan kebutuhan awal dalam pengembangan sistem informasi izin produk makanan.

\section{B. Perencanaan}

Setelah diketahui kebutuhan dalam proses pengembangan sistem informasi izin produk makanan seperti yang diperlihatkan pada Gambar 2 dan pada tahapan eksplorasi maka pada tahapan ini dilakukan perencanaan. Perencanaan yang dibuat adalah perencanaan bagaimana proses pengerjaan sistem informasi. Gambar 3 dapat dilihat adalah proses perencanaan. Dapat diketahui sesuai Gambar 3 bahwa proses pengerjaan dimulasi dari pengumpulan kebutuhan, perancangan, prototyping (iterasi), pengujian dan delivery produk.

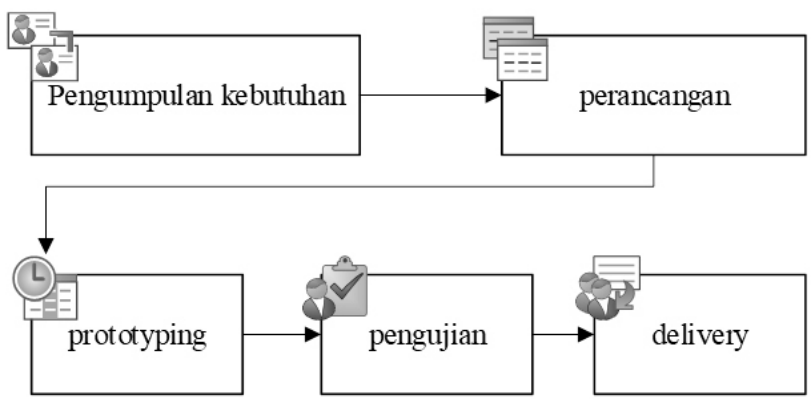

Gambar 3. Perencanaan pengerjaan sistem informasi

\section{Iterasi Pengembangan}

Proses iterasi pengembangan merupakan proses pembuatan struktur pembentuk sistem informasi izin produk makanan. Dalam membuat iterasi pengembangan ini dibuat menggunakan diagram unified modeling language (UML).

ISSN : 2301-7988

E-ISSN : 2581-0588

DOI $: 10.32736 /$ sisfokom.v8i2.679 
UML adalah teknik pemodelan yang mampu menyederhakan permasalahan objek dan mudah untuk dipahami. Dalam melakukan pemodelan UML memiliki konsep dasar berupa konsep abstraksi yang dikelompokkan kedalam beberapa jenis diagram yaitu "structure classification, dynamic behavior, dan model management" [13]. Untuk itu pada Gambar 4 dan Gambar 5 dapat dilihat bagaimana salah satu diagram UML yang menggambarkan behavior dari sistem infromasi izin produk makanan.

Seperti yang ditampilkan pada Gambar 4 dan Gambar 5 dapat diketahui bahwa terdapat dua tipe pengguna dalam sistem informasi izin produk makanan yaitu masyarakat dan administrator. Untuk jenis pengguna masyarakat terdapat beberapa aktivitas yang dapat dilakukan yaitu membaca berita, melihat daftar produk dan melihat satus izin produk, memberikan pengaduan dan mengisi buku tamua.

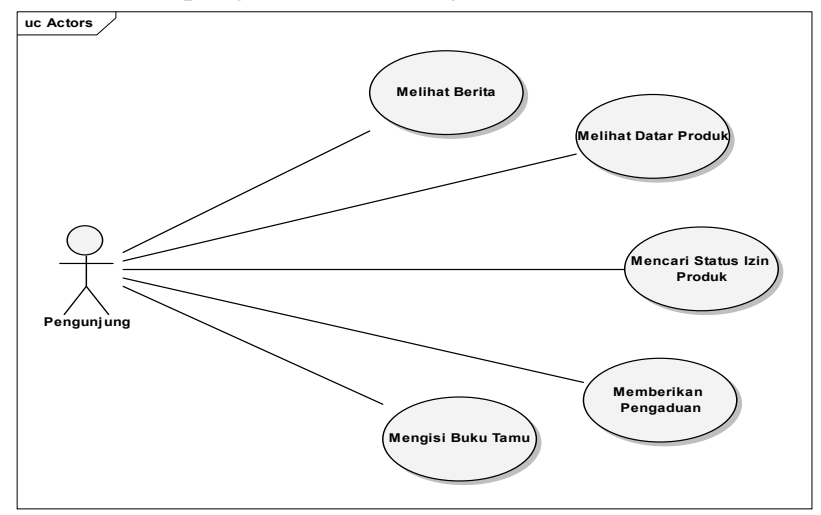

Gambar 4. Use case diagram pengunjung (masyarakat)

Sedangkan pengguna dengan jenis administrator memiliki beberapa aktifitas yaitu mengelola data kategori produk, mengelola data produk mengelola data izin produk, mengelola data berita dan melihat pengaduan masyarakat.

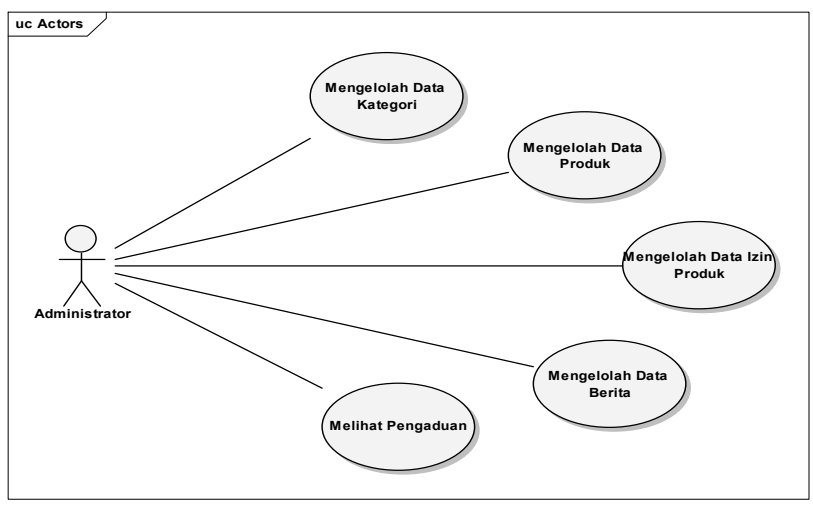

Gambar 5. Use case diagram administrator

Sebagai pembentuk struktur sistem infromasi izin produk makanan terdapat lima pembentuk utama seperti yang diperlihatkan pada Gambar 6 yang terdiri dari kategori, produk, izin produk, berita dan pengaduan. Struktur tersebut seperti yang digambarkan dalam class diagram berikut.

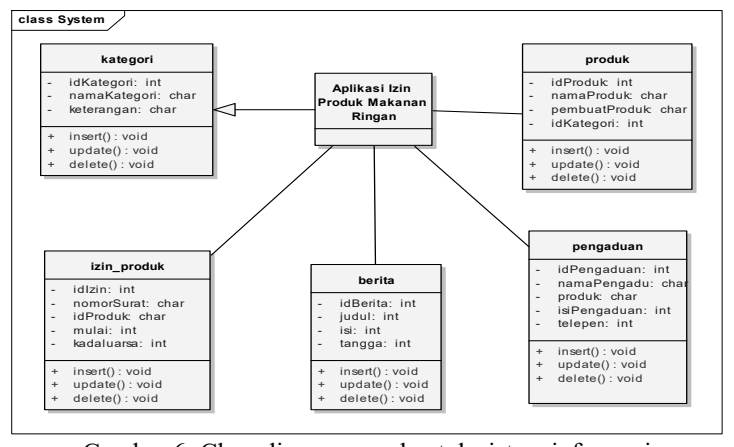

Gambar 6. Class diagram pembentuk sistem informasi

\section{Produksi}

Dari hasil eksplorasi perencanaan sampai dengan iterasi pengembangan yang telah dilakukan sebelumnya maka dapat dilihat hasil produksi pada Gambar 7. pada Gambar 7 merupakan salah satu tampilan implementasi sistem informasi izin produk makanan yaitu untuk halaman (menu) data izin produk.

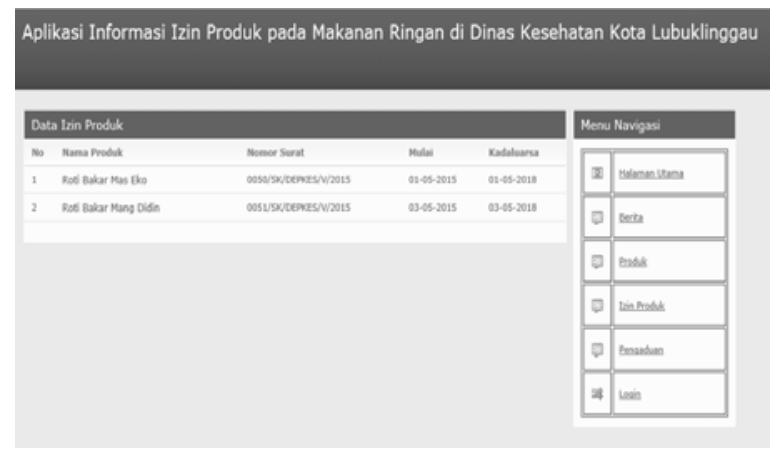

Gambar 7. Halaman izin produk makanan

Selain melihat data izin produk seperti yang diperlihatkan pada Gambar 7 masyarakat juga dapat melakukan pengaduan kepada pihak pemerintah. Proses pengaduan tersebut seperti yang diperlihatkan pada Gambar 8. Pada proes pengaduan data yang diperlukan yaitu nama pengadu, produk yang menjadi objek aduan, telapon pihak pengadu serta isi aduan. Setiap data aduan dapat dilihat oleh administrator dan menjadi masukkan pemerintah untuk melakukan tindakan.

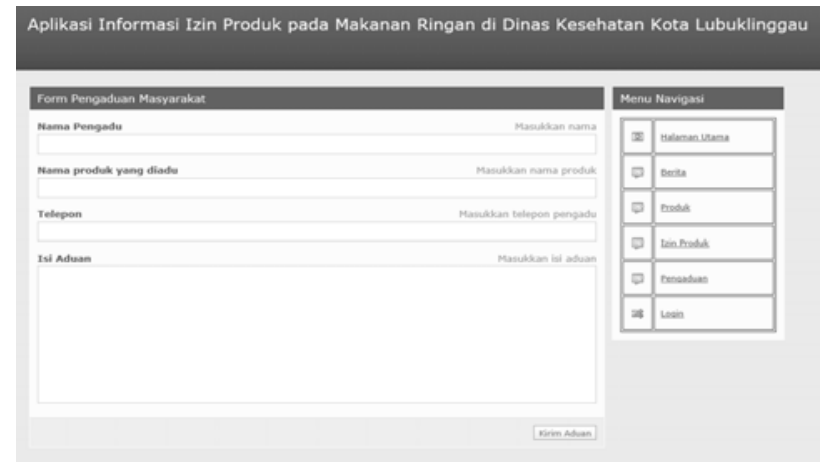

Gambar 8. Form pengaduan masyarakat 
Informasi lain yang dapat dilihat oleh masyarakat memiliki kesamaan seperti yang diperlihatkan pada sttruktur menu navigasi kebutuhan awal pengembangan sistem informasi izin produk makanan seperti Gambar 2. Untuk menjamin produk yang dihasilkan maka dilakukan pengujian untuk setiap komponen sistem informasi. Pengujian merupakan proses verifikasi dan validasi apakah sistem infromasi yang dihasilkan telah berfungsi dengan baik atau tidak. Untuk itu proses pengujian ini dilakukan dengan teknik pengujian black box [14]. Pengujian black box merupakan jenis pengujian perangkat lunak atau sistem informasi yang menekannkan kepada input dan output atau dengan kata lain fungsional perangkat lunak atau sistem informasi. untuk itu dapat dilihat hasil pengujian untuk masing-masing komponen sistem informasi izin produk makanan seperti yang diperlihatkan dari Tabel 1 sampai dengan Tabel 5.

TABLE I. HASIL PenguJian Login

\begin{tabular}{|c|l|}
\hline \multicolumn{3}{|c|}{ Kasus dan Hasil Ujicoba (Data Benar) } \\
\hline Data masukan & Username : admin Password : admin \\
\hline $\begin{array}{c}\text { Yang } \\
\text { diharapkan }\end{array}$ & $\begin{array}{l}\text { Setelah mengisi username dan password yang } \\
\text { benar kemudian klik button login maka akan } \\
\text { menampilkan halaman utama administrator } \\
\text { simpeke }\end{array}$ \\
\hline Pengamatan & $\begin{array}{l}\text { Username dan password yang dimasukan dapat } \\
\text { diterima dan button login berfungsi dengan baik } \\
\text { dan dapat menampilkan halaman administrator } \\
\text { simpeke }\end{array}$ \\
\hline Kesimpulan & {$[\checkmark$ ] Diterima [ ] Ditolak } \\
\hline \multicolumn{2}{|c|}{ Kasus dan Hasil Ujicoba (Data Salah) } \\
\hline Data masukan & Username : admin Password : passalah \\
\hline Yang & $\begin{array}{l}\text { Setelah mengisi username dan password maka } \\
\text { menekan button login, kemudian halaman login } \\
\text { ditampilkan kembali }\end{array}$ \\
\hline Pengamatan & $\begin{array}{l}\text { Setelah memasukan username dan password yang } \\
\text { tidak sesuai maka menampilkan halaman login } \\
\text { kembali }\end{array}$ \\
\hline Kesimpulan & {$[\checkmark$ ] Diterima [ ] Ditolak } \\
\hline
\end{tabular}

TABle II. PEngujian Data Kategori

\begin{tabular}{|c|l|}
\hline \multicolumn{2}{|c|}{ Kasus dan Hasil Ujicoba } \\
\hline Input data Kategori \\
\hline Data masukan & $\begin{array}{l}\text { Memasukan data Kategori sesuai dengan field yang } \\
\text { disediakan sediakan }\end{array}$ \\
\hline $\begin{array}{c}\text { Yang } \\
\text { diharapkan }\end{array}$ & $\begin{array}{l}\text { Proses masukkan data. Klik button simpan data, } \\
\text { data disimpan ke database dan menampilkan daftar } \\
\text { data kategori }\end{array}$ \\
\hline Pengamatan & $\begin{array}{l}\text { Data kategori berhasil dimasukan ke database dan } \\
\text { menampilkan data kategori, sesuai dengan yang } \\
\text { diharapkan }\end{array}$ \\
\hline Kesimpulan & $\sqrt{ }$ [] Diterima [ ] Ditolak \\
\hline \multicolumn{2}{|c|}{ Edit data kategori } \\
\hline Data masukan & $\begin{array}{l}\text { Memilih kategori yang akan diubah dari daftar data } \\
\text { kategori }\end{array}$ \\
\hline Yang & $\begin{array}{l}\text { Dapat menampilkan form edit, dapat merubah data } \\
\text { kategori, kemudian proses disimpan, menampilkan } \\
\text { edit sukses dilakukan dan kembali ke daftar } \\
\text { kategori }\end{array}$ \\
\hline Pengamatan & $\begin{array}{l}\text { Data kategori dapat di edit dan kembali ke daftar } \\
\text { data kategori }\end{array}$ \\
\hline Kesimpulan & {$[\checkmark$ ] Diterima [ ] Ditolak } \\
\hline \multicolumn{2}{|c|}{ Delete data Kategori } \\
\hline Data masukan & Memilih data kategori pada daftar kategori \\
\hline Yang & menampilkan pesan proses penghapusan data \\
\hline
\end{tabular}

\begin{tabular}{|c|l|}
\hline \multicolumn{2}{|c|}{ Kasus dan Hasil Ujicoba } \\
\hline \multicolumn{2}{|c|}{ Input data Kategori } \\
\hline diharapkan & berhasil, dan kembali ke daftar data kategori \\
\hline Pengamatan & $\begin{array}{l}\text { Menampilkan pesan penghapusan data berhasil dan } \\
\text { kembali ke daftar data kategori }\end{array}$ \\
\hline Kesimpulan & {$[\checkmark$ ] Diterima [ ] Ditolak } \\
\hline
\end{tabular}

TABle III. Pengujian Data Produk

\begin{tabular}{|c|l|}
\hline \multicolumn{2}{|c|}{ Kasus dan Hasil Ujicoba } \\
\hline \multicolumn{2}{|c|}{ Input data Produk } \\
\hline Data masukan & $\begin{array}{l}\text { Memasukan data Produk sesuai dengan field yang } \\
\text { disediakan sediakan }\end{array}$ \\
\hline $\begin{array}{c}\text { Yang } \\
\text { diharapkan }\end{array}$ & $\begin{array}{l}\text { Proses masukkan dat. Klik button simpan data, data } \\
\text { disimpan ke database dan menampilkan daftar data } \\
\text { Produk }\end{array}$ \\
\hline Pengamatan & $\begin{array}{l}\text { Data Produk berhasil dimasukan ke database dan } \\
\text { menampilkan data Produk, sesuai dengan yang } \\
\text { diharapkan }\end{array}$ \\
\hline Kesimpulan & $\checkmark$ ] Diterima [ ] Ditolak \\
\hline \multicolumn{2}{|c|}{ Edit data Produk } \\
\hline Data masukan & $\begin{array}{l}\text { Memilih Produk yang akan diubah dari daftar data } \\
\text { Produk }\end{array}$ \\
\hline $\begin{array}{c}\text { Yang } \\
\text { diharapkan }\end{array}$ & $\begin{array}{l}\text { Dapat menampilkan form edit, dapat merubah data } \\
\text { Produk, kemudian proses disimpan, menampilkan } \\
\text { edit sukses dilakukan dan kembali ke daftar Produk }\end{array}$ \\
\hline Pengamatan & $\begin{array}{l}\text { Data Produk dapat di edit dan kembali ke daftar } \\
\text { data Produk }\end{array}$ \\
\hline Kesimpulan & {$[\checkmark$ ] Diterima [ ] Ditolak } \\
\hline \multicolumn{2}{|c|}{ Delete data Produk } \\
\hline Data masukan & Memilih data Produk pada daftar Produk \\
\hline $\begin{array}{c}\text { Yang } \\
\text { diharapkan }\end{array}$ & $\begin{array}{l}\text { menampilkan pesan proses penghapusan data } \\
\text { berhasil, dan kembali ke daftar data Produk }\end{array}$ \\
\hline Pengamatan & $\begin{array}{l}\text { Menampilkan pesan penghapusan data berhasil dan } \\
\text { kembali ke daftar data Produk }\end{array}$ \\
\hline Kesimpulan & $\sqrt{ }$ ] Diterima [ ] Ditolak \\
\hline
\end{tabular}

TABle IV. Pengujian Data Izin Produk

\begin{tabular}{|c|c|}
\hline \multicolumn{2}{|r|}{ Kasus dan Hasil Ujicoba } \\
\hline \multicolumn{2}{|r|}{ Input data Izin produk } \\
\hline Data masukan & $\begin{array}{l}\text { Memasukan data Izin produk sesuai dengan field } \\
\text { yang disediakan sediakan }\end{array}$ \\
\hline $\begin{array}{c}\text { Yang } \\
\text { diharapkan }\end{array}$ & $\begin{array}{l}\text { Proses masukkan dat. Klik button simpan data, data } \\
\text { disimpan ke database dan menampilkan daftar data } \\
\text { Izin produk }\end{array}$ \\
\hline Pengamatan & $\begin{array}{l}\text { Data Izin produk berhasil dimasukan ke database } \\
\text { dan menampilkan data Izin produk, sesuai dengan } \\
\text { yang diharapkan }\end{array}$ \\
\hline Kesimpulan & {$[\checkmark]$ Diterima [ ] Ditolak } \\
\hline \multicolumn{2}{|r|}{ Edit data Izin produk } \\
\hline Data masukan & $\begin{array}{l}\text { Memilih Izin produk yang akan diubah dari daftar } \\
\text { data Izin produk }\end{array}$ \\
\hline $\begin{array}{c}\text { Yang } \\
\text { diharapkan }\end{array}$ & $\begin{array}{l}\text { Dapat menampilkan form edit, dapat merubah data } \\
\text { Izin produk, kemudian proses disimpan, } \\
\text { menampilkan edit sukses dilakukan dan kembali ke } \\
\text { daftar Izin produk }\end{array}$ \\
\hline Pengamatan & $\begin{array}{l}\text { Data Izin produk dapat di edit dan kembali ke } \\
\text { daftar data Izin produk }\end{array}$ \\
\hline Kesimpulan & {$[\checkmark]$ Diterima [ ] Ditolak } \\
\hline \multicolumn{2}{|r|}{ Delete data Izin produk } \\
\hline Data masukan & Memilih data Izin produk pada daftar Izin produk \\
\hline $\begin{array}{c}\text { Yang } \\
\text { diharapkan }\end{array}$ & $\begin{array}{l}\text { menampilkan pesan proses penghapusan data } \\
\text { berhasil, dan kembali ke daftar data Izin produk }\end{array}$ \\
\hline Pengamatan & $\begin{array}{l}\text { Menampilkan pesan penghapusan data berhasil dan } \\
\text { kembali ke daftar data izin produk }\end{array}$ \\
\hline Kesimpulan & {$[\checkmark]$ Diterima [ ] Ditolak } \\
\hline
\end{tabular}


TABle V. Pengujian Data Pengaduan

\begin{tabular}{|c|l|}
\hline \multicolumn{2}{|c|}{ Kasus dan Hasil Ujicoba } \\
\hline \multicolumn{2}{|c|}{ Delete data pengaduan } \\
\hline Data masukan & Memilih data pengaduan pada daftar pengaduan \\
\hline $\begin{array}{c}\text { Yang } \\
\text { diharapkan }\end{array}$ & $\begin{array}{l}\text { menampilkan pesan proses penghapusan data } \\
\text { berhasil, dan kembali ke daftar data pengaduan }\end{array}$ \\
\hline Pengamatan & $\begin{array}{l}\text { Menampilkan pesan penghapusan data berhasil dan } \\
\text { kembali ke daftar data pengaduan }\end{array}$ \\
\hline Kesimpulan & {$[\checkmark]$ Diterima [ ] Ditolak } \\
\hline
\end{tabular}

Hasil pengujian menggunakan teknik black box seperti yang ditampilkan pada Tabel 1 sampai dengan Tabel 5 menunjukkan bahwa semua komponen sistem informasi izin produk makanan dikategorikan diterima. Maksud dari diterima adalah sistem infomrasi dapat berjalan dengan benar sesuai harapan atau dengan kata lain mampu berfungsi dengan baik.

\section{KESIMPULAN}

Sesuai uraian yang telah dikemukakan dalam proses implementasi extreme programming dalam pengembangan sistem informasi izin produk makanan ini dapat disimpulkan beberapa hal yaitu: (1) sistem informasi izin produk makanan telah dikembangakan menggunakan extreme programming merupakan metode pengembangan yang terstruktur, sistematis dan berorientasi objek (pengguna). (2) Sistem informasi yang dihasilkan memiliki fitur yang mampu menampilkan izin produk makanan sehingga dapat memudahkan masyarakat dalam mencari informasi izin produk makanan. (3) sistem informasi izin produk makanan layak untuk digunakan sesuai yang dibutktikan dari hasil pengujian menyatakan dapat diterima atau dengan kata lain semua fungsi sistem informasi berjalan dengan baik.

\section{ACKNOWLEDGMENT}

Terima kasih kami sampaikan kepada semua pihak atas terlaksananya penelitian ini baik kepada Universtias Bina Darma sebagai penyandang dana maupun kepada pemerintah daerah di Provisnsi Sumatra Selatan yang telah memberikan dukungan berupa akses informasi. Terima kasih juga kami sampaikan kepada redaksi Jurnal Sisfokom yang telah bersedia meluangkan waktu untuk melakukan review dan menerbitkan artikel ini.

\section{REFERENSI}

[1] G. W. Sasmito, "Penerapan Metode Waterfall Pada Desain Sistem Informasi Geografis Industri Kabupaten Tegal," Jurnal Informatika: Jurnal Pengembangan IT, vol. 2, no. 1, pp. 6-12, 2017.

[2] S. Nugroho, S. H. Waluyo, and L. Hakim, "Comparative analysis of software development methods between Parallel, V-Shaped and Iterative," walden dissertations and doctoral studies, 2017.
[3] A. Muharom, R. Cahyana, and H. Bunyamin, "Pengembangan Aplikasi Sunda Berbasis Android Menggunakan Metode Rapid Application Development (RAD)," Jurnal Algoritma, vol. 10, no. $1,2013$.

[4] A. Noertjahyana, "Studi Analisis Rapid Aplication Development Sebagai Salah Satu Alternatif Metode Pengembangan Perangkat Lunak," Jurnal Informatika, vol. 3, no. 2, pp. 64-68, 2004.

[5] R. W. Witjaksono, N. Ambarsari, and M. A. Sadewo, "Penerapan Erp Modul Warehouse Management Pada Waroenk Laundry Dengan Metode Spiral," JRSI (Jurnal Rekayasa Sistem dan Industri), vol. 2, no. 01, pp. 19-26, 2016.

[6] B. O. Lubis, "Penerapan Global Extreme Programming Pada Sistem Informasi Workshop, Seminar Dan Pelatihan Di Lembaga Edukasi," Jurnal Informatika, vol. 3, no. 2, 2016.

[7] R. Rahmi, R. P. Sari, and R. Suhatman, "Pendekatan Metodologi Extreme Programming pada Aplikasi E-Commerce (Studi kasus Sistem Informasi Penjualan Alat-alat Telekomunikasi)," Jurnal Komputer Terapan, vol. 2, no. 2, pp. 83-92, 2016.

[8] M. Rahardjo, "Studi kasus dalam penelitian kualitatif: konsep dan prosedurnya," 2017.

[9] U. Ependi, T. B. Kurniawan, and F. Panjaitan, "SYSTEM USABILITY SCALE VS HEURISTIC EVALUATION: A REVIEW," Simetris: Jurnal Teknik Mesin, Elektro dan Ilmu Komputer, vol. 10, no. 1, pp. 65-74, 2019.

[10] R. Ferdiana, Rekayasa Perangkat Lunak yang Dinamis dengan Global Extreme Programming. Yogyakarta: Andi, 2012.

[11] U. Ependi, "Geographic Information System Produksi Energi dan Pertambangan Kabupaten Musi Banyuasin," Jurnal Nasional Teknologi dan Sistem Informasi, vol. 3, no. 3, pp. 360-369, 2017.

[12] E. B. Pratama, "Pendekatan Metodologi Extreme Programming pada Aplikasi e-Commerce Berbasis M-Commerce (Studi Kasus: Toko Buku An’Nur di Pontianak)," Jurnal Khatulistiwa Informatika, vol. 5, no. 2, 2017.

[13] U. Ependi, "Pemodelan Sistem Informasi Monitoring Inventory Sekretariat Daerah Kabupaten Musi Banyuasin," KLIK-KUMPULAN JURNAL ILMU KOMPUTER, vol. 5, no. 1, pp. 4960, 2018.

[14] U. Ependi, "Uji Coba Dan Implementasi Test Engine System Bina Darma Career And Training Center," Jurnal Sistem Informasi, vol. 9, no. 1, pp. 1222-1232, 2017. 